\title{
EDITORIAL
}

\section{Somos diversos}

Las razones por las cuales un médico elige una especialidad son obviamente muy variadas. Las elecciones vocacionales que realizamos después de la escuela de medicina, hace tiempo comenzaron a ser materia de estudio, debido a la posibilidad de orientar a las personas a tomar mejores decisiones.

Holland y su teoría de las Elecciones Vocacionales, por ejemplo, ha sido una de las más extensamente investigadas y aplicadas. La teoría incorpora conceptos sobre personalidad, comportamiento vocacional, psicología y estereotipos sociales. Aplicada a los médicos y sus decisiones, esta teoría ejemplifica cómo profesionales de personalidades similares se agrupan en torno a una misma especialidad; como J. K. Rowling escribe en Harry Potter "es la varita la que elige al mago y no el mago el que elige la varita".

En Radiología, por su parte, nos corresponde enfrentar patologías provenientes de todas las áreas de la medicina y esta es la razón por la que en la medida que privilegiamos un área de desarrollo nos vamos relacionando con grupos específicos de profesionales que comparten con nosotros los logros y la satisfacción de trabajar por el bien de un grupo determinado de pacientes, en un área de interés común. Si pensamos que, como radiólogos nuestro ambiente nos modela, Holland diría que, muy por el contrario, nuestra personalidad ha influido en nuestras motivaciones y en las metas que nos hemos ido imponiendo en nuestro camino profesional.

Esta diversidad, inherente a nuestra especialidad hace que, por ejemplo, consejeros académicos de grandes universidades, a la hora de recomendar a sus estudiantes, describan la Radiología como una especialidad dinámica, ligada a variadas modalidades de imágenes, tecnológicamente cambiantes; involucrada en el diagnóstico, tratamiento y seguimiento de niños, jóvenes, ancianos, hombres o mujeres; trabajando en una oficina o en un hospital; lejos del paciente o en contacto directo con él; laborando ya sea en horario de oficina, los fines de semana o de madrugada.

Sobre las características del radiólogo, varios están de acuerdo en lo difícil que se ha hecho caracterizar a los radiólogos en un solo tipo. Pareciera en verdad, que las seis categorías de Holland tienen representación y espacio en nuestra especialidad. Compartimos con colegas radiólogos que a diario nos entregan su visión realista de nuestra práctica con algunas coincidencias con los que son convencionales o con aquellos que están siempre preocupados por los aspectos sociales de nuestro trabajo, que crece y se complejiza de la mano de los investigadores y los emprendedores, y que trasciende con el toque de los artistas. Sin embargo, todas las descripciones coinciden en lo que parece en verdad ser nuestra verdadera pasión: resolver problemas y explicar la solución a otros.

Para los médicos clínicos, nuestra actividad formal o informalmente, se ha ido elevando a la categoría de interconsultores. Para nosotros, nuestro empeño seguirá puesto en reconocer y relacionar hallazgos, en conectar alteraciones que no se explican en forma obvia, en dar importancia a lo que otros pasaron por alto, en ver lo que nadie más vio.

Para los admiradores de Joseph Bell y Sherlock Holmes va nuestro esfuerzo editorial de este número.

Dr. Marcelo Gálvez M.

Editor Científico 